\title{
Occurrence of Blue Green Algae from Maize Fieldsof Mohol Tahasil in Solapur
}

\author{
Seema Khadatare ${ }^{1}$, D. S. Suryawanshi ${ }^{2}$ \\ ${ }^{1,2}$ Department of Botany, Jawahar Arts, Science and Commerce College, Andur, Tal.Tuljapur, Dist. Osmanabad.
}

\begin{abstract}
Blue-green algae make a major contribution to the fertility of the soil. It has been suggested that blue-green algae (BGA) assist higher plant growth by supplying growth substances. There are numerous works about roles of blue-green algae on growth of maize fields. Increase in use of synthetic fertilizers in the field badly affected the fertility of the soil. These synthetic fertilizers are effecting on flora and fauna of the field responsible for productivity of the crop plants. Most of the farmers are utilizing these fertilizers blindly to increase productivity. To check proper dosage and relative abundance of the blue green algae efforts were made to evaluate abundance of blue green algae from Mohol tehsil of Solapur district. During the investigations, 19 species of bluegreen algaebelonging to three families of heterocystous and non-heterocystous from maize fields in MoholTahasil ofsolapurdistrict were identified, out of which seven species are new to this region.
\end{abstract}

Keywords: Blue green Algae, biofertilizer, Cyanophyta,Solapur

\section{Introduction}

Cyanobacteria represent a small taxonomic groupof photosynthetic prokaryotes which some of them areable to $\mathrm{N}_{2}$ fixation and also possess a tremendouspotential for producing a wide range of secondarymetabolites. Cyanobacteria have drawn much attention asprospective and rich sources of biologically activeconstituents and have been identified as one of the mostpromising groups of organisms capable of producing bioactive compounds (Fish \&Codd 1994, Schlegel et al.1999). Production of bioactive molecules such as auxins,production of secondary metabolites linked to bio controlof bacterial and fungal diseases as well as improvingsoil structure and porosity through secretion ofpolysaccharides aiding in soil aggregation are the mostimportant functions of these microorganisms(Karthikeyanet al. 2007, Sergeevaet al. 2002). $\operatorname{De}(1939)$ attributed the natural fertility of maize fieldsoil and its maintenance to the process of biologicalnitrogen fixation by cyanobacteria. This was the firstreport, which recognized the agronomic potential ofcyanobacteria in India. The widespread application ofsingle element fertilizers (especially $\mathrm{N}$ in Asiancountries) in the cultivation of major crops has led toaccelerated exhaustion of other major and minor nutrients leading to nutrient imbalances and poor soilfertility. In the current scenario therefore, an urgent needhas been felt to deploy microbial bio-fertilizer which aremultifaceted such as cyanobacterialbiofertilizer. As yetfor substitution of chemical fertilizers by microbialbio fertilizers many studies have been done. Gupta \&Shukla (1967) studied the algal influence on growth,yield and protein content of maize plants and showed thatpre-soaking maize seeds with BGA cultures or extractsenhances germination, promotes the growth of roots andshoots, and increases the weight and protein content ofthe grain.

Svircevet al. (1997) also reported that plantgrowth was enhanced in the presence of cyanobacterium,even without organic $\mathrm{N}$ fertilizer application. Beneficialeffects of cyanobacterial inoculation were reported, not only for maize, but for other crops such as wheat, soybean,oat, tomato, radish, cotton, sugarcane, chili, bean,muskmelon and lettuce (Venkataraman 1972, Rodgerset al. 1979, Singh 1988, Arifet al. 1995, Thajuddin\&Subramanian 2005, Saadatnia\&Riahi 2009, Maqubelaet al. 2008, Karthikeyanet al. 2007). Several reasonshave been proposed for beneficial effects ofcyanobacteria on the growth of different plants. Thecapacity for biosynthesis of growth promoting substancessuch as auxins, amino acids, sugars and vitamins(Vitamin B12, Folic acid, Nicotinic acid and Pantothenicacid) was reported by Misra\&Kaushik (1989 a, b) thatcan enhance growth of plant.

Additionally, cyanobacteriaexcrete complex organic carbon compounds that bind tothe soil particles and improve soil aggregation, henceimprove soil structure, soil permeability and waterholding capacity of soil (Kaushik 2007). However, todate, the effect of single species cyanobacteriabiofertilizer on plant growth has not yet been fullyinvestigated. The primary aim of this research was tostudy cyanobacteria species isolated from soil.

There are numerous works about roles of blue-green algae on growth of maize fields. Increase in use of synthetic fertilizers in the field badly affected the fertility of the soil. These synthetic fertilizers are effecting on flora and fauna of the field responsible for productivity of the crop plants. Most of the farmers are utilizing these fertilizers blindly to increase productivity. To check proper dosage and relative abundance of the blue green algae efforts were made to evaluate abundance of blue green algae from Mohol tehsil of Solapur district.

\section{Materials and Methods}

Soil samples were collected from the depth of $0-5 \mathrm{~cm}$ on severalmaize fields in Moholtahasilof Solapur district of Maharashtra.(Rangaswamy 1996).

- Isolation of cyanobacteria:

Soil samples were transferred to sterile Petridishes and added to them sterilized BG-11 medium withpH: 7.1. The Petri dishes were placed in a culturechamber at $25^{\circ} \mathrm{C}$ and a 


\section{International Journal of Science and Research (IJSR) \\ ISSN (Online): 2319-7064 \\ Index Copernicus Value (2013): 6.14 | Impact Factor (2015): 6.391}

12/12 h light dark cycle atartificial illumination (2000-2500 Lux) for two weeks.After colonization, for purification, identification andmultiplication of colonies, a part of each colony wasremoved by a loop and transferred to a new plate. Afterpurification of taxa, taxonomic determination was carriedout by light microscopy and based on Desikachary(1959), Prescott (1970) and Wehret al. (2002), and corrected based on algaebase website(www.algaebase.org).

\section{Results}

In the present study, seven taxa of heterocystous and12 taxa of non-heterocystouscyanophyta were identified.Nostocaceaewith four genera and seven species,Oscillatoriaceaewith three genera and six species andChroococcaceaewith four genera and six species wereincluded in the list of isolates (Table 1).
Table 1: The list of Cyanobacterial taxa occurred in MoholTahasil

\begin{tabular}{|c|c|c|}
\hline Nostocaceae & Oscillatoriaceae & Chroococcaceae \\
\hline $\begin{array}{c}\text { Anabaena } \\
\text { vaginicolaF.E. Fritsch } \\
\text { \& Rich }\end{array}$ & $\begin{array}{c}\text { Oscillatoria } \\
\text { angustissimaW.W } \\
\text { est\&G.S.West }\end{array}$ & $\begin{array}{l}\text { Aphanothecegelat } \\
\text { inosa(Hennings } \\
\text { )Lemmermann }\end{array}$ \\
\hline $\begin{array}{l}\text { Cylindrospermummich } \\
\text { ailovskoenseElenkin }\end{array}$ & $\begin{array}{c}\text { Oscillatoria } \\
\text { chilkensisBiswas }\end{array}$ & $\begin{array}{l}\text { Chroococcusminu } \\
\text { tus(Kützing) } \\
\text { Nägeli }\end{array}$ \\
\hline $\begin{array}{l}\text { Nostocpunctiforme(Kü } \\
\text { tzing) Hariot }\end{array}$ & $\begin{array}{l}\text { Phormidiumtereb } \\
\text { riforme(C. } \\
\text { Agardh ex } \\
\end{array}$ & $\begin{array}{l}\text { Chroococcusmini } \\
\text { mus(Keissler) } \\
\text { Lemmermann }\end{array}$ \\
\hline $\begin{array}{c}\text { NostocmuscorumC. } \\
\text { Agardh ex } \\
\text { Bornet\&Flahault }\end{array}$ & $\begin{array}{c}\text { Gomont) } \\
\text { Anagnostidis\&Ko } \\
\text { márek }\end{array}$ & $\begin{array}{c}\text { Chroococcuspalli } \\
\text { dus(Nägeli) } \\
\text { Nägeli }\end{array}$ \\
\hline $\begin{array}{c}\text { NostoccalcicolaBrébis } \\
\text { son ex } \\
\text { Bornet\&Flahault }\end{array}$ & $\begin{array}{l}\text { Phormidiumgran } \\
\text { ulatum(Gardner) } \\
\text { Anagnostidis }\end{array}$ & Gleocapsasp. \\
\hline Nostocsp. & $\begin{array}{c}\text { Phormidiumartic } \\
\text { ulatum(Gardner) } \\
\text { Anagnostidis\&Ko } \\
\text { márek }\end{array}$ & Gloeothecesp. \\
\hline $\begin{array}{c}\text { Nodulariaharveyana(T } \\
\text { hwaites) Thuret }\end{array}$ & Lyngbyasp. & \\
\hline
\end{tabular}

Among these taxa, three species of heterocystouscyanobacteria, Anabaena vaginicola, Nostocsp. andNodulariaharveyana, which were isolated from maize fieldsoils.

Table 2: Total percent abundance of cyanobacteria genera (summed up over all locations)

\begin{tabular}{|c|c|c|c|c|c|c|}
\hline Genus & \multicolumn{4}{|c|}{ Localities in MoholTahasil } & Total No. of species & Percentabundance \\
\hline & Anagar & Aasti & Penar & Kamati & & \\
\hline Anabaena & + & + & + & + & 2 & 5.2 \\
\hline Nostoc & + & + & + & + & 4 & 21 \\
\hline Cylindrospermum & - & - & + & + & 1 & 5.2 \\
\hline Nodularia & + & + & + & + & 2 & 5.2 \\
\hline Oscillatoria & + & + & - & + & 2 & 10.6 \\
\hline Phormidium & - & - & - & - & 3 & 16 \\
\hline Chroococcus & + & + & + & + & 3 & 16 \\
\hline Aphanothece & + & + & + & + & 1 & 5.2 \\
\hline Gloeothece & + & + & - & - & 1 & 5.2 \\
\hline Gleocapsa & + & - & + & + & 2 & 5.2 \\
\hline
\end{tabular}

Abundance of these species was studied of these species. It was observed that Nostocwas most abundant with $25 \%$ occurance followed by Phromidium andchroccusup to 16 percentage followed by Oscillatoria with $10.6 \%$. This was followed by Anabaena, Cylendrospermu, Nodularia, Aphanotheca, GloeothecaandGloeocapsa with $5.2 \%$.

\section{Conclusion}

From the above results it could be concluded that Nostocis the dominating blue green algae plays its role in productivity of maize crop. Promidium and Chroococcusare the second largest species play their vital role productivity of crops and are the second largest group of blue green algae. If dose of synthetic utilized properly, they may nurture are favorable for the growth of blue green algae. This will lead to fertility of soil and will definitely effect on productivity of crop plants such as Maize.

\section{Acknowledgement}

Authors are thankful to Principal,Jawahar Arts, Science and Commerce College, Andur, Tal. Tuljapur, Dist. Osmanabad for providing laboratory facilities to carry out the research work. 


\section{International Journal of Science and Research (IJSR) \\ ISSN (Online): 2319-7064}

Index Copernicus Value (2013): 6.14 | Impact Factor (2015): 6.391
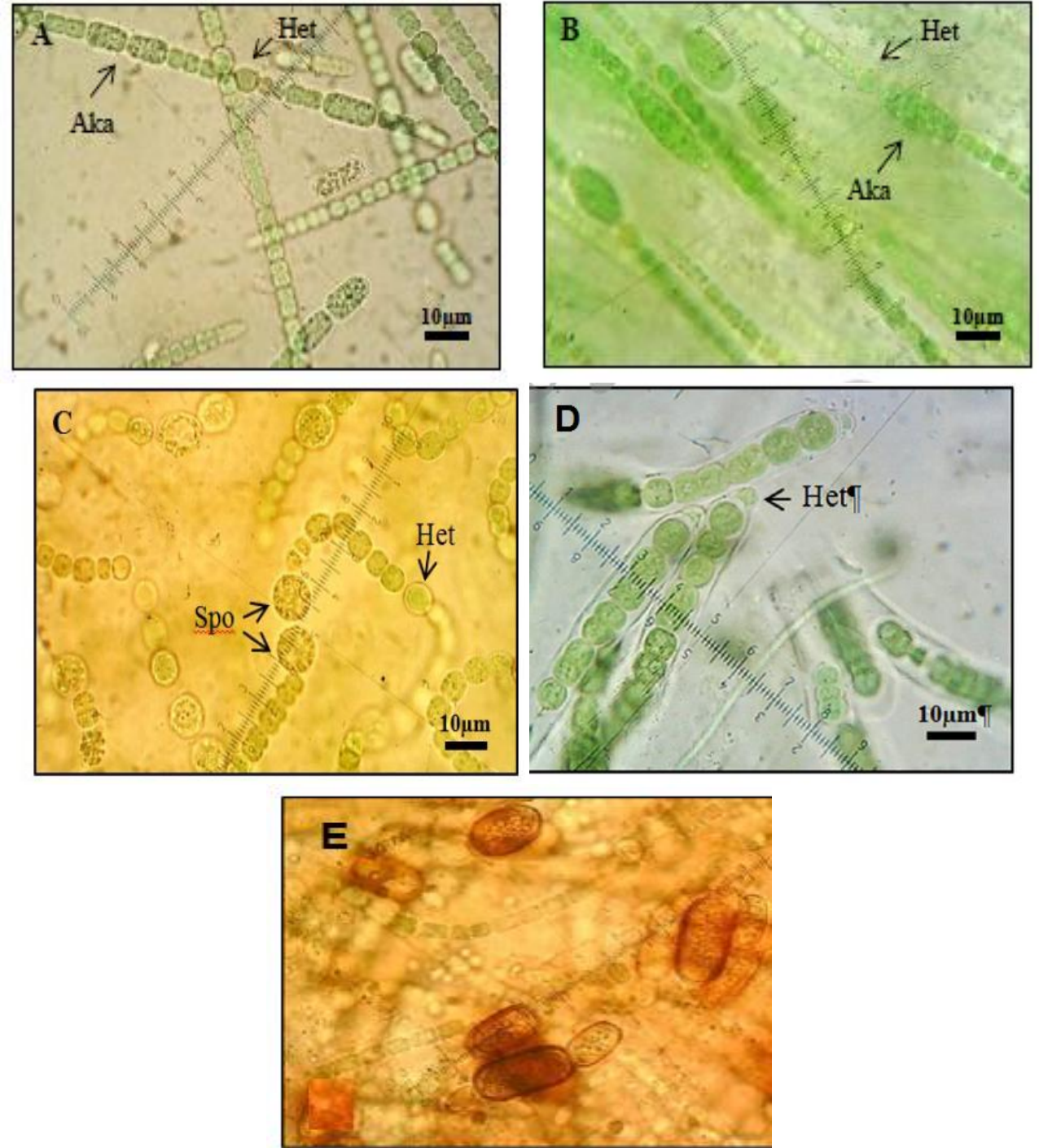

Figure: A, Anabaena inaequalis; B, Anabaena fuellborni; C, Nostocpruniforme D. Calothrixfusca E. Cylendrospermum

\section{References}

[1] Desikachary, T.V. 1959.Cyanophyta. New Delhi: IndianCouncil of Agricultural Research. 686 pp.

[2] De, P.K. 1939. The role of blue-green algae in nitrogenfixation in rice fields. Proceeding of the RoyalSociety of London. Series B 127: 121-139.

[3] Fish, S.A. \&Codd, G.A. 1994. Bioactive compoundproduction by thermophilic and thermo tolerantcyanobacteria (blue-green algae). World Journalof Microbiology and Biotechnology 10:338-347.

[4] Karthikeyan, N., Prasanna, R., Nain, L. \&Kaushik, B.D.2007. Evaluating the potential of plant growthpromoting cyanobacteria as inoculants forwheat. European Journal of Soil Biology 43: 23-30.

[5] Kaushik,

B.D. 2007.Cyanobacterialbiofertilizertechnology. Pp. 53-59. In: S. Kannaiyan, K.Kumar \& K. Govindarajan (eds). Biofertilizerstechnology. Scientific Publishers. India.

[6] Maqubela, M.P., Mnkeni, P.N.S., Malamissa, O.,Pardo, M.T. \&Acqui, L.P.D. 2008. Nostoccyanobacterial inoculation in South Africanagricultural soils enhances soil structure, fertilityand maize growth. Plant and Soil 315: 79-92.
[7] Misra, S. \&Kaushik, B.D. 1989a. Growth promotingsubstances of cyanobacteria I. Vitamins and theirinfluence on rice plant. Proceeding of the IndianScience Academy B55: 295-300.

[8] Misra, S. \&Kaushik, B.D. 1989b. Growth promotingsubstances of cyanobacteria II. Detection ofamino acids, sugars and auxins. Proceeding ofthe Indian Science Academy B55: 499-504.

[9] Prescott, G.W. 1970. Algae of the western great lakesarea. WM. C. Brown Company Publishers.977 pp.

[10] Rangaswamy, G. 1996. Agricultural microbiology. AsiaPublishing House, Bombay, p. 54-76.

[11] Saadatnia, H. \&Riahi, H. 2009. Cyanobacteria frompaddy-fields in Iran as a biofertilizer in riceplants. Plant Soil Environment 55(5): 207-212.

[12] Schlegel, I., Doan, N.T., De Chazol, N. \&Smit, G.D.1999. Antibiotic activity of new cyanobacterialisolates from Australia and Asia against greenalgae and cyanobacteria. Journal of AppliedPhycology 10: 471-479.

[13] Sergeeva, E., Liaimer, A. \& Bergman, B. 2002.Evidence for production of the phytohormoneindole-3-acetic acid by cyanobacteria. Planta215: 229-238. 


\section{International Journal of Science and Research (IJSR) \\ ISSN (Online): 2319-7064}

Index Copernicus Value (2013): 6.14 | Impact Factor (2015): 6.391

[14] Singh, P.K. 1988. Biofertilization of rice crop. pp.109114. In: S.P. Sena. \& P.C. Palit (eds).Biofertilizationpolentialities and problems.Plant Physiology Forum.

[15] Svircev, Z., Tomas, I., Nenin, P. \&Drobac, A. 1997.Co-cultivation of N2-fixing cyanobacteria andsome agriculturally important plants in liquidand sand culture. Applied Soil Ecology 6:74-81.

[16] Thajuddin, N. \& Subramanian, G. 2005.Cyanobacterialbiodiversity and potential application inbiotechnology. Current Science 89: 47-57.

[17] Venkataraman, G.S. 1972. Algal biofertilizer and ricecultivation. Today and Tomorrows Printer andPublishers. New Delhi. 71 pp.

[18] Venkataraman, G.S. \&Neelakantan, S. 1967. Effect ofthe cellular constituents of the nitrogen fixingbluegreen algae Cylindrospermummuscicolaonthe root growth of rice seedlings. Journal ofGeneral and Applied Microbiology 13: 53-61.

[19] Wehr, J.D., Sheath, R.G. \& Thorp, J.H. 2002.Freshwater algae of North America: Ecology andclassification. Aquatic Ecology Press. 917 pp.

[20] http://www.algaebase.org 